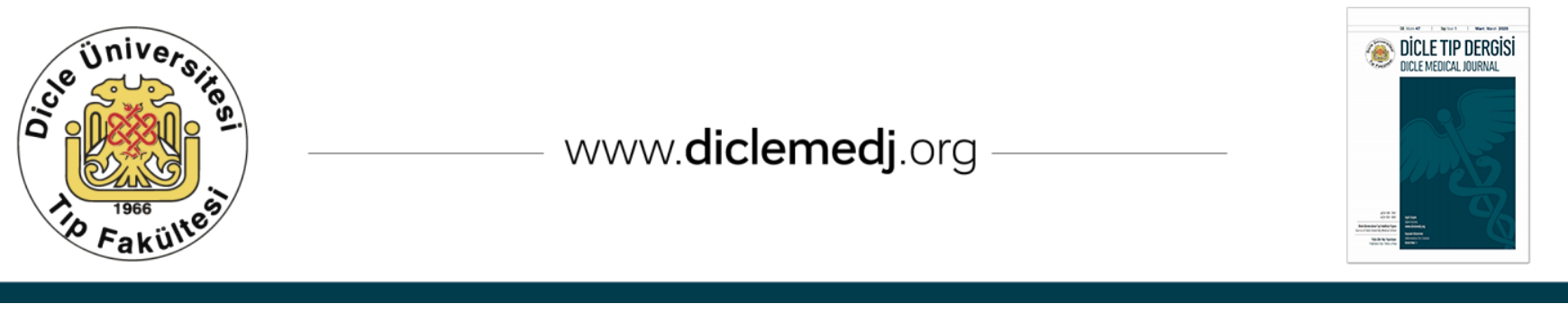

Original Article / Özgün Araştırma

\title{
Intact Fibroblast Growth Factor 23 and Peripheral Vascular Complications in Patients on Hemodialysis
}

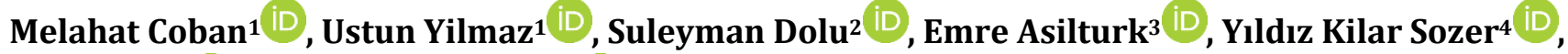 \\ Bekir Erol4 $^{\text {iD }}$, Hamit Yasar Ellidag 5 iD
}

1 Department of Nephrology, Antalya Training and Research Hospital, Antalya, Turkey

2 Department of Internal Medicine, Antalya Training and Research Hospital, Antalya, Turkey

3 Department of Cardiology, Antalya Training and Research Hospital, Antalya, Turkey

4 Department of Radiology, Antalya Training and Research Hospital, Antalya, Turkey

5 Department of Biochemistry, Antalya Training and Research Hospital, Antalya, Turkey

Received: 22.10.2019; Revised: 23.12.2019; Accepted: 07.01.2020

\begin{abstract}
Objective: Peripheral vascular complications frequently seen in hemodialysis patients are associated with mortality. Fibroblast growth factor 23 (FGF23) is thought to be a phosphaturic hormone that causes mortality in hemodialysis patients. The purpose of our study was to determine the association of intact FGF23 (I-FGF23) with atherosclerotic peripheral vascular complications in patients on hemodialysis.
\end{abstract}

Methods: This cross-sectional study was performed with 50 [28 (56\%) male, 22 (44\%) female] hemodialysis patients. Patient characteristics were compared with an age +- and sex-matched control group of 40 healthy volunteers. Atherosclerosis development was measured by carotid intima media thickness (CIMT) and arterial stiffness development was measured by brachial ankle pulse wave velocity (PWV) device.

Results: Increased atherosclerosis and arterial stiffness were observed in patients with high I-FGF23 and low alpha klotho $(\alpha-\mathrm{KL})$ levels compared to healthy subjects. I-FGF23 showed an inverse and independent relationship between lipid profile. There was no relationship between I-FGF23 and atherosclerosis and arterial stiffness.

Conclusion: There was no association between serum I-FGF23 and atherosclerotic peripheral vascular complications. The association between I-FGF23 and mortality may be due to cardiovascular events other than peripheral vascular complications in patients on hemodialysis.

Keywords: Atherosclerosis, arterial stiffness, hemodialysis, intact fibroblast growth factor 23, alpha klotho 


\section{Hemodiyaliz Hastalarında Intak Fibroblast Büyüme Faktörü 23 ve Periferik Damar Komplikasyonları}

\section{Öz}

Amaç: Hemodiyaliz hastalarında sık görülen periferik damar komplikasyonları mortalite ile ilişkilidir. Fibroblast büyüme faktörü 23 (FGF23)'ün hemodiyaliz hastalarında mortaliteye neden olan fosfatürik bir hormon olduğu düşünülmektedir. Çalışmamızın amacı, hemodiyaliz hastalarında intak FGF23 (I-FGF23) ile aterosklerotik periferik damar komplikasyonları arasındaki ilişkiyi belirlemekti.

Yöntemler: Bu kesitsel çalışma 50 [28 (\%56) erkek, 22 (\%44) kadın] hemodiyaliz hastası ile yapıldı. Hastalar yaş ve cinsiyet benzer 40 sağlıklı bireyle karşılaştırıldı. Ateroskleroz gelişimi karotis intima media kalınlığı (KIMK) ve arteriyel sertlik gelişimi brakiyal ayak bileği nabzı dalga hızı (NDH) aleti ile belirlendi.

Bulgular: Hastalarda sağlıklı bireylere göre yüksek I-FGF23 düzeyleri ve düşük alfa-klotho ( $\alpha$-KL) düzeyleri ile birlikte artmış ateroskleroz ve arteriyel sertlik gelişimi gözlendi. I-FGF23 ile lipid profili arasında ters ve diğer faktörlerden bağımsız bir ilişki gözlendi. I-FGF23 ile ateroskleroz ve arteriyel sertlik arasında ilişki gözlenmedi.

Tartışma: Serum I-FGF23 ile aterosklerotik periferik damar komplikasyonları arasında ilişki yoktu. Hemodiyaliz hastalarında I-FGF23 ile mortalite arasındaki ilişkinin nedeni periferik damar komplikasyonları dışındaki diğer kardiyovasküler olaylardan kaynaklanıyor olabilir.

Anahtar kelimeler: Ateroskleroz, arteriyel sertlik, hemodiyaliz, intak fibroblast büyüme faktörü 23, alfa-klotho.

\section{INTRODUCTION}

Fibroblast growth factor 23 (FGF23) is a factor that is primarily synthesized in bones and it takes part in phosphate homeostasis ${ }^{1}$. FGF23, binds to its receptors in the kidney via binding with alpha klotho ( $\alpha$-KL), which is its coreceptor, FGF23 inhibits renal phosphate (P) excretion by inhibiting sodium (Na)P-IIa transporters in the proximal tubules, and reduces the synthesis of ${ }^{1}$. 25hydroxyvitaminD3 (1.250H2VitD3). Serum FGF23 levels increase by 100 to 1000 fold in patients on hemodialysis compared with chronic kidney disease patients.

Increased intima media thickness in the arteries is thought to be an early indicator of atherosclerosis. Atherosclerotic changes can be detected using ultrasonography (USG) or magnetic resonance imaging. Measurement of carotid intima media thickness (CIMT) by USG is a preferred non-invasive, inexpensive, and easily applicable method for determining whether atherosclerosis developed ${ }^{2}$. Increased
CIMT values can be used as an early indicator of the development of atheroclerosis in the brain, and peripheral and coronary artery vessels. In the chronic kidney disease patients; the increased number of endothelial microparticles due to hyperparathyroidism and increased calcium-phosphate multiplication lead to changes in the structure of the arteries, causing atherosclerosis. Lipid abnormalities and disorders of bone mineral balance are the risk factors for development of the atherosclerosis in patients on hemodialysis. A study reported development of atherosclerosis with increased CIMT measurement in patients on hemodialysis ${ }^{3}$. Similarly, another study reported a relationship between the serum FGF23 and atherosclerosis in these patients4. In contrast, another study reported no association between the FGF23 and atherosclerosis in patients on hemodialysis ${ }^{5}$.

Determination of arterial stiffness development by using the brachial ankle pulse wave velocity 
(PWV) device is an easy and reproducible technique, showing good correlation with data obtained with the carotid femoral PWV device, known to be the gold standard method. A study reported an association between FGF23 and arterial stiffness on predialysis chronic kidney disease patients 6 ; however, whereas other studies reported no association between them ${ }^{7,8}$.

In chronic kidney disease patients, cardiovascular (CV) complications are increased due to the direct impact of FGF23 in addition to the effects of altered mineral metabolism. Even though high serum FGF23 levels induce myocardial cell hypertrophy in hemodialysis patients, the relationship of the elevated I-FGF23 serum levels with the structural changes in the peripheral vessels is still being investigated ${ }^{9}$. Although the correlation between the increased FGF23 and mortality in hemodialysis patients has already been established, the underlying mechanism of this relationship is still unknown ${ }^{10}$. Therefore; this study aimed to determine the association of intact FGF23 (I-FGF23) with atherosclerosis and arterial stiffness, which are the peripheral vascular complications, in patients on hemodialysis.

\section{METHODS}

\section{Study population}

This cross-sectional study included with 50 [28 (56\%) male / 22 (44\%) female] hemodialysis patients. The study was conducted in the hemodialysis unit from March 2017 to April 2018. We investigated the differences between the patients and 40 healthy controls, who did not have a history of comorbid diseases or regular medication use. The eligible patients; who were over 18 years old, underwent hemodialysis treatment for more than 12 months, had a Kt $/ \mathrm{V}(\mathrm{K}=$ Filter clearance, $\mathrm{t}=$ time of a dialysis session, $\mathrm{V}=$ distribution volume of urea) value of $>1.2$ for last 12 months. The patients; who did not agree to participate were included in the study, the patients with a life expectancy of less than 1 year, active malignancy, active infection, a history of a peripheral vascular disease (mesenteric ischemia, cerebrovascular event, carotid artery stenosis, atherosclerosis obliterans, claudications, Buerger's disease) or intervention (sympathectomy, amputation), a history of a cardiac disease (angina pectoris, left ventricular ejection fraction $<50 \%$, ischemic heart disease, dilated or hypertrophic cardiomyopathy, arrhythmia) or cardiac interventions (coronary bypass grafting, placement of stent or cardiac pacemakers, metallic heart valve replacement) were excluded. The content of the study was explained to all eligible patients, and their consents were received. Consent forms printed on paper were obtained from the ethics committee of the hospital, explaining the feasibility of the study.

\section{Clinical assessments and laboratory tests}

Demographic data of the study patients, the medications they received, and the etiology of end-stage renal disease (ESRD) were recorded. Blood pressure (BP) values of the patients were measured before the hemodialysis sessions. Participants who had a history of high BP, or who had a systolic BP of $\geq 140 \mathrm{mmHg}$ and/or diastolic BP of $\geq 90 \mathrm{mmHg}$ or who received antihypertensives were considered as hypertensive.

After 10-12 hours of overnight fasting, the blood samples were collected and then centrifuged for 15 minutes at $4{ }^{\circ} \mathrm{C}$. The elicited supernatants were stored at $-80^{\circ} \mathrm{C}$. Routine biochemical tests for the following variables; including (calcium (Ca), phosphate (P), creatinine, totalcholesterol (T-C), high-density lipoprotein cholesterol (HDL-C), and triglyceride) levels were performed with Beckman Coulter commercial kits and autoanalyzer. The levels of low-density lipoprotein cholesterol (LDL-C) 
were determined according to the formula of Friedewald: (T-C)-(HDL-C)- (triglyceride/5) 11. Parathyroid hormone levels were determined with chemiluminescence method, using a Beckman Coulter D x I800 (Beckman Coulter Inst., San Diego, USA) instrument. The levels of 1.25 - dihydroxyvitaminD3 $(1.25(\mathrm{OH})$ 2VitD3 (Bioassay Lab., Shanghai, China) were determined by the enzyme-linked immunoadsorbent assay (ELISA). The levels of 25-hydroxy vitaminD3 $(25(\mathrm{OH}) \mathrm{D} 3)$ levels were determined with the chemiluminescence method by a Liason (DiaSorin, MN, USA) instrument. Intact fibroblast growth factor 23 (I-FGF23) and alpha klotho ( $\alpha$-KL) (Elabscience, China) levels were determined by enzymelinked immunosorbent assay.

\section{Hemodialysis Session}

All patients were dialyzed with bicarbonate dialysate and polysulfane dialyzer (Fresenius, Hamburg, Germany). Standard unfractionated heparin was used for anticoagulation. Each hemodialysis session took 4 hours and the patients underwent HD 3 days, a week. The mean blood flow rate during an hemodialysis session was $300 \mathrm{~mL} / \mathrm{min}(250-350 \mathrm{~mL} / \mathrm{min})$. The composition of the dialysate fluid values was follows: sodium (Na) $140 \mathrm{mmol} / \mathrm{L}$, potassium (K) $1-3 \mathrm{mmol} / \mathrm{L}, \mathrm{Ca} 1.5 \mathrm{mmol} / \mathrm{L}$ and bicarbonate $33 \mathrm{mmol} / \mathrm{L}$. The dry weight of the patients was described as the weight without hypervolemia signs and symptoms (orthopnea, dyspnea, and edema) between two dialysis sessions. The $\mathrm{Kt} / \mathrm{V}$ value was calculated according to the Daugirdas formula ${ }^{12}$.

\section{Assessment of Atherosclerosis}

Carotid intima media thickness (CIMT) value was measured by ultrasonography (USG) device (Siemens, Los Angeles, CA, USA) with a 8-10 $\mathrm{MHz}$ probe. Bilateral carotid arteries, carotid bifurcation, and the first 2 centimeters lenght of the internal carotid artery were measured. CIMT value was determined by measuring the longitudinal distance from the vascular lumen echogenicity to the media/adventitia echogenicity ${ }^{13}$. An CIMT value of $\geq 0.9 \mathrm{~mm}$ was considered atherosclerosis.

\section{Assessment of Arterial Stiffness}

A brachial ankle pulse wave velocity (PWV) device (Stolberg, Germany) was used for assessing arterial stiffness14. Time of transit (TT) value was calculated as the difference between the onset and termination of the waves measured in the brachial-tibial arteries and brachial-ankle. The distance between the suprasternal notch and the brachium (SNB) and the distance between the suprasternal notch and the ankle (SNA) values were calculated. The (SNA-SNB)/TT formula was used for calculating the brachial ankle PWV. For calculating the augmentation index (AIx) the ascending arterial pressure waveform of the reflected wave was divided by the pulse pressure.

\section{Statistical Analysis}

Continuous data were expressed as mean \pm standard deviation, whereas categorical data were expressed as ratio and percentage (\%) values. Mann-Whitney $U$ test was used for quantitative variables with non-normal distribution and the Student $\mathrm{t}$ test was used for quantitative variables with normal distribution. Pearson Chi-square and Fisher's Exact test was used for categorical variables. For determining the relationship between $\log 10$ I-FGF23 values and the values of CIMT and brachial ankle PWV, Spearman rank test was used for non-normally distributed data and Pearson test was used for normally distributed data. Multiple regression analysis was used for identifying the variables independenting for affecting the $\log 10$ I-FGF23 values. For all parameters, $p<0.05$ values was accepted as statistically significant.

\section{RESULTS}

Hemodialysis patients have significantly higher serum levels of Ca, PTH, T-C, LDL-C, I-FGF23 and 
significantly lower serum levels of HDL-C, 25(OH)D3, 1.25(OH)2VitD3 than healthy subjects. In addition, increased atherosclerosis and AS were observed in patients compared to healthy individuals. There was no correlation between I-FGF23 and atherosclerosis and AS development. When patients were divided into two groups according to mean I-FGF23 (2.4 $\mathrm{pg} / \mathrm{mL}$ ) levels, there was no significant difference between the two groups regarding the duration of dialysis, anti-hypertensive and anti-phosphate drug use, atherosclerosis and AS development. In multivariate analysis, there was an independent inverse relationship between I-FGF23 and T-C, triglyceride, LDL-C, while no relationship was found between IFGF23 and peripheral vascular complications.

\section{DISCUSSION}

In our study, we have investigated the relationship of the I-FGF23 with atherosclerosis and arterial stiffness, which are the peripheral vascular complications, in patients on hemodialysis. High serum levels of I-FGF23 and low serum $\alpha$-KL levels were observed in hemodialysis patients compared to healthy individuals. Furthermore, it was found out that atherosclerosis and arterial stiffness developed more in hemodialysis patients compared to healthy individuals.

Although the association between the high serum FGF23 levels and increased CV complications in hemodialysis patients has already been established ${ }^{15}$, the causes underlying these relationships still need to be laborated further ${ }^{10}$. In one of the study on hemodialysis patients, high serum levels of FGF23 and CIMT-associated atherosclerosis were shown to be related ${ }^{16}$. Another study reported that, FGF23 was involved in the pathogenesis of atherosclerosis in hemodialysis patients ${ }^{17}$. In contrast, in a study on hemodialysis patients FGF23 was reported to play a protective role in the development of peripheral vascular complications ${ }^{18}$. Similarly, another study reported an inverse relationship between FGF23 and atherosclerosis in hemodialysis patients ${ }^{19}$. In our study, we observed no correlations between the I-FGF23 levels and atherosclerosis in hemodialysis patients, similar to the results of a previously reported another study ${ }^{20}$. Furthermore, there was not a difference in the development of atherosclerosis between the groups with high and low I-FGF23 levels. It was also observed that there was an inverse relationship of the IFGF23 levels with the T-C, and triglyceride and LDL-C levels. Ashikaga et al. reported an inverse relationship between the FGF23 levels and the lipid parameters, which are the two players taking part in the development of atherosclerosis in hemodialysis patients. The same study also reported that FGF23 improve the serum lipid levels in patients on hemodialysis ${ }^{19}$. The preclinical study of Tomlinson et al. was conducted on mice, reporting that high serum fibroblast growth factor 19 levels were associated with an improvement in lipid levels ${ }^{21}$. Similarly; another preclinical study on mice conducted by, Huang et al. reported that triglyceride levels returned to normal with the administration of intravenous fibroblast growth factor $21^{22}$. There is a molecular similarity between FGF23, and fibroblast growth factor 19 and fibroblast growth factor 21, which belong to the fibroblast growth factor 19 subfamily, taking an effective part in lipid metabolism ${ }^{23}$. Furthermore; similar to other molecules, FGF23 has been shown to cause regression atherosclerosis associated with serum T-C, LDL-C and triglyceride levels in patients on hemodialysis.

A study on hemodialysis patients demonstrated, the association of FGF23 with arterial stiffness in peripheral vessels ${ }^{24}$. On the contrary, another study suggested that the unfavorable effects of FGF23 on the CV system were independent of its effects on peripheral vessels ${ }^{25}$. Another study in the literature showed no association between 
FGF23 and atherosclerosis in hemodialysis patients ${ }^{26}$. Shimada et al., in their study conducted on mice, suggested that FGF23 had a protective effect on the development of arterial stiffness $^{27}$. Lindberg et al. suggested that the synthesis of $\alpha$-KL, the FGF23 coreceptor on peripheral vessels, is minimal or absent in mice ${ }^{28}$. Scialla et al., in their in vitro study on human smooth muscle cells, reported that exposure to FGF23 did not result in calcifications, and that no synthesis of I-FGF23 and its co-receptor KL occurred in the peripheral vessels ${ }^{8}$. A brachial-ankle PWV device was has been used in our study for evaluation of arterial stiffness because it provides results similar to those obtained with the carotid femoral PWV device, which has been reported as theis device of the first choice in studies conducted with chronic kidney disease patients ${ }^{29}$. Moreover, and the brachial-ankle PWV device is easy to use. In our study, correlation was not found out between I-FGF23 and arterial stiffness in hemodialysis patients. This may be explained based on the results of the previous studies reporting that I-FGF23 does not affect the peripheral vessels in hemodialysis patients due to little or no I-FGF23 receptor synthesis in these vessels ${ }^{19}$.

There are some limitations to our study. First, our study was performed in a single center. Secondly, because our study was crosssectional, it was not possible to determine the long-term effects of I-FGF23 and peripheral vascular complications in hemodialysis patients. Third, the effects of other risk factors on the development of peripheral vascular complications were not ruled out because the antihypertensive and antiphosphate medication used of the patients continued throughout the study. Fourth, although I-FGF23 levels were statistically significant between the groups, its clinical significance and usage are not clear according to the current study results. Absence of carotid-femoral PWV device, which is the gold standard for the detection of arterial stiffness, and the absence of intravascular USG $^{30}$, which is the gold standard for the detection of atherosclerosis, may have affected our results.

In conclusion, our results suggest that higher IFGF23 and lower $\alpha$-KL levels were observed in patients on hemodialysis compared to healthy participants. No relations of I-FGF23 to atherosclerosis and arterial stiffness was observed in hemodialysis patients. Also, there was an inverse relationship of the I-FGF23 levels and with the levels of T-C, triglyceride and LDL-C. The relationship between the I-FGF23 levels and increased mortality in hemodialysis patients is reflected in $\mathrm{CV}$ complications rather than the development of atherosclerosis and arterial stiffness, which are the atherosclerotic peripheral vascular complications. The effects of I-FGF23 levels on the peripheral vascular system in hemodialysis patients may evolve via different mechanism independent of its effect on other cells of the CV system. Nevertheless, there is a need for further large-scale and multicentered studies, investigating the relationship between I-FGF23 and peripheral blood vessel complications to provide more insight into the grounds of this relationship in hemodialysis patients.

Ethics Committee Approval: Consent forms printed on paper were obtained from the ethics committee of the hospital, explaining the feasibility of the study.

Conflict of interest: Authors have nothing to declare.

Financial Disclosure: The authors declared that this study has received no financial support.

\section{REFERENCES}

1. Liu S, Gupta A, Quarles LD. Emerging role of fibroblast growth factor 23 in a bone-kidney axis regulating systemic phosphate 
homeostasis and extracellular matrix mineralization. Curr Opin Nephrol Hypertens 2007; 16: 329-35.

2. O'Leary DH, Polak JF. Intima-media thickness: a tool for atherosclerosis imaging and event prediction. Am J Cardiol 2002; 90: 18L-21L.

3. Lindner A, Charra B, Sherrard DJ, Scribner BH. Accelerated atherosclerosis in prolonged maintenance hemodialysis. N Engl J Med 1974; 290: 697-701.

4. Balci M, Kirkpantur A, Gulbay M, Gurbuz A. Plasma fibroblast growth factor-23 levels are independently associated with carotid artery atherosclerosis in maintenance hemodialysis patients. Hemodial Int 2010; 14: 425-32.

5. Turan MN, Kircelli F, Yaprak M, et al. FGF-23 levels are associated with vascular calcification, but not with atherosclerosis, in hemodialysis patients. Int Urol Nephrol. 2016; 48: 609-17.

6. Mirza MA, Larsson A, Lind L, Larsson TE. Circulating fibroblast growth factor-23 is associated with vascular dysfunction in the community. Atherosclerosis 2009; 205: 385-90.

7. Desjardins L, Liabeuf S, Renard C, et al. FGF23 is independently associated with vascular calcification but not bone mineral density in patients at various CKD stages. Osteoporos Int 2012; 23: 2017-25.

8. Scialla JJ, Lau WL, Reilly MP, et al. Fibroblast growth factor 23 is not associated with and does not induce arterial calcification. Kidney Int 2013; 83: 1159-68.

9. Ibrahim WH, Ahmad AB, Sayed NG. Association of serum fibroblast growth factor23 with Doppler pulse wave velocity in hemodialysis patients. Saudi J Kidney Dis Transpl 2018; 29: 95-100.

10. Wolf M, Molnar MZ, Amaral AP, et al. Elevated fibroblast growth factor 23 is a risk factor for kidney transplant loss and mortality. J Am Soc Nephrol 2011; 22: 956-66.
11. Friedewald WT, Levy RI, Fredrickson DS. Estimation of the concentration of low-density lipoprotein cholesterol in plasma, without use of the preparative ultracentrifuge. Clin Chem 1972; 18: 499-502.

12. Daugirdas JT. Second generation logarithmic estimates of single-pool variable volume $\mathrm{Kt} / \mathrm{V}$ : An analysis of error. J Am Soc Nephrol 1993; 4: 1205-13.

13. Homma S, Hirose N, Ishida H, Ishii T, Araki G. Carotid plaque and intima-media thickness assessed by B-mode ultrasonography in subjects ranging from young adults to centenarians. Stroke 2001; 32: 830-5.

14. Yokoyama H, Shoji T, Kimoto E, et al. Pulse wave velocity in lower-limb arteries among diabetic patients with peripheral arterial disease. J Atheroscler Thromb 2003; 10: 253-8.

15. Jean G, Terrat JC, Vanel T, et al. High levels of serum fibroblast growth factor (FGF)-23 are associated with increased mortality in long haemodialysis patients. Nephrol Dial Transplant 2009; 24: 2792-6.

16. Hussein HS, Allam LE, Mohab A, Elbarghouty NM, Mohammed SY. Fibroblast Gross Factor-23 and Arterial Stiffness in Hemodialysis Patients. Int J Clin Cardiol Res 2017; 1: 067-71.

17. Zeng Y, Feng S, Han OY, et al. Role of fibroblast growth factor-23 in the pathogenesis of atherosclerosis in peritoneal dialysis patients. Genet Mol Res 2015; 14: 719-29.

18. Inaba M, Okuno S, Imanishi $Y$, et al. Role of fibroblast growth factor-23 in peripheral vascular calcification in non-diabetic and diabetic hemodialysis patients. Osteoporos Int 2006; 17: 1506-13.

19. Ashikaga E, Honda H, Suzuki H, et al. Impact of fibroblast growth factor 23 on lipids and atherosclerosis in hemodialysis patients. Ther Apher Dial 2010; 14: 315-22. 
20. Park KA, Jo HM, Han JS, et al. Features of atherosclerosis in hemodialysis patients. Kidney Res Clin Pract 2013; 32: 177-82.

21. Tomlinson E, Fu L, John L, et al. Transgenic mice expressing human fibroblast growth factor-19 display increased metabolic rate and decreased adiposity. Endocrinology 2002; 143: 1741-7.

22. Huang X, Yang C, Luo Y, et al. FGFR4 prevents hyperlipidemia and insulin resistance but underlies high-fat diet induced fatty liver. Diabetes 2007; 56: 2501-10.

23. Zhang F, Yu L, Lin X, et al. Minireview: Roles of Fibroblast Growth Factors 19 and 21 in Metabolic Regulation and Chronic Diseases. Mol Endocrinol 2015; 29: 1400-13.

24. Jean G, Bresson E, Terrat JC, et al. Peripheral vascular calcification in long-haemodialysis patients: associated factors and survival consequences. Nephrol Dial Transplant 2009; 24: 948-55.

25. Manghat P, Souleimanova I, Cheung J, et al. Association of bone turnover markers and arterial stiffness in pre-dialysis chronic kidney disease (CKD). Bone 2011; 48: 1127-32.
26. Moldovan D, Moldovan I, Rusu C, et al. FGF23, vascular calcification, and cardiovascular diseases in chronic hemodialysis patients. Int Urol Nephrol 2014; 46: 121-8.

27. Shimada T, Kakitani M, Yamazaki Y, et al. Targeted ablation of FGF23 demonstrates an essential physiological role of FGF23 in phosphate and vitamin D metabolism. J Clin Invest 2004; 113: 561-8.

28. Lindberg K, Olauson H, Amin R, et al. Arterial klotho expression and FGF23 effects on vascular calcification and function. PLoS One 2013; 8: e60658.

29. Tsuchikura S, Shoji T, Kimoto E, et al. Brachial-ankle pulse wave velocity as an index of central arterial stiffness. J Atheroscler Thromb 2010; 17: 658-65.

30. Bernini G, Galetta F, Franzoni F, et al. Arterial stiffness, intima-media thickness and carotid artery fibrosis in patients with primary aldosteronism. J Hypertens 2008; 26: 2399-405. 